\title{
Effect of dietary proportion of grass silage on milk fat with emphasis on odd- and branched-chain fatty acids in dairy cows
}

\author{
M. Patel, ${ }^{1}$ E. Wredle, and J. Bertilsson \\ Swedish University of Agricultural Sciences, Department of Animal Nutrition and Management, Kungsängen Research Centre, \\ SE-753 23 Uppsala, Sweden
}

\begin{abstract}
High proportions of forage in diets fed to dairy cows are interesting options in conventional production, and mandatory in organic dairy farming (e.g., within the European Union). The objectives of the present study were to study the milk fatty acid (FA) profiles, with particular focus on the odd- and branched-chain FA (OBCFA) and their association with diet composition, using 3 different proportions of grass silage in the diet. The OBCFA profiles in milk have been suggested to be potential markers to assess nutrient supply to the cows. The study included data from 24 cows in 2008 and 26 cows in 2009, using pooled milk samples from morning and evening milking within $24 \mathrm{~h}$. The 3 diets were composed of the same feeds: grass silage and grainbased concentrate, but the silage component was fed in different proportions, namely 50,70 , and $85 \%$ of total dry matter intake. The cows were in late lactation, with a mean of $220(\mathrm{SD}=15)$ days in milk in 2008, and $216(\mathrm{SD}=35)$ days in milk in 2009 , at the onset of the trial. Increased proportions of grass silage in the diet increased the intake of C18:3n-3, and decreased the intake of C18:2n-6 and intake of total FA. The daily intake of C18:3n-3 and C18:2n-6 was reflected in a similar increase in milk C18:3n-3, whereas the concentration of milk C18:2n-6 decreased with increasing proportion of grass silage in the diet. Increased proportions of grass silage in the diet increased the concentration of conjugated linoleic acid and the linear odd-chain FA C15:0 and $\mathrm{C} 17: 0$, the branched-chain iso $\mathrm{C} 15: 0$ and total OBCFA in milk. The concentration of total OBCFA in milk was shown to be positively correlated with dietary content of neutral detergent fiber. This suggests that the concentration of milk OBCFA may be useful in the future to indicate low forage intake in cows under conditions when it is not possible to measure individual forage intake.
\end{abstract}

Received February 16, 2012.

Accepted September 10, 2012.

${ }^{1}$ Corresponding author: Mikaela.Patel@slu.se
Key words: forage-to-concentrate ratio, forage proportion, grass silage, fatty acid profile

\section{INTRODUCTION}

Milk fat contains approximately 2 to $3 \%$ odd- and branched-chain FA (OBCFA) derived from the membrane lipids of rumen microbes. The OBCFA profiles in milk have been suggested to be potential markers for duodenal flow of microbial protein (Cabrita et al., 2003; Vlaeminck et al., 2005), and of individual VFA in rumen fluid (Vlaeminck et al., 2006c). Thus, they could be used as noninvasive tools for researchers as well as a tool for farmers to assess nutrient supply to the cows. Furthermore, Colman et al. (2010) and AlZahal et al. (2011) showed that certain milk OBCFA (mainly iso $\mathrm{C} 13: 0$ and iso $\mathrm{C} 16: 0$ ) were potential predictors of ruminal acidosis.

In conventional milk production in Sweden, diets, on average, contain 40 to $50 \%$ forage on a yearly DM basis (Emanuelson et al., 2006). The regulations for organic dairy farming within the European Union stipulate that at least $60 \%$ of the daily DMI should consist of forage (EC, 2008). A combination of grass silage and grainbased concentrates is the most common diet for dairy cows in Scandinavia throughout the year, regardless of production system. This combination is also common practice during the winter months in pasture-based dairy systems in temperate areas in Europe. Larger proportions of forage than $50 \%$ of DM are often used in these forage-dominated systems. In commercial herds, farmers often do not have control of the individual forage intakes of each cow. A cow with a low forage intake can, therefore, pass unnoticed, and health problems such as acidosis can arise. It is, therefore, interesting to study if OBCFA can be used as an indicator of some important aspects of the nutritional status of the cow.

The FA composition in cow milk can be altered through feeding. Changing the forage source or the forage proportion are well-known means to alter the FA profile in milk, and addition of lipid supplements can cause more substantial changes in the milk fat composition (Chilliard et al., 2007). Several studies have 
investigated the effects of different feeds and feed additives. Some authors have studied the effect of forageto-concentrate ratio on FA profiles in milk, but in these studies, the concentrates have been fed at flat rates and DMI has varied between treatment groups (Dewhurst et al., 2003b). In other cases, corn silage and oil supplements have been used in combination with concentrate (Shingfield et al., 2005), or the forages have been of considerably lower nutritional quality (Khiaosa-Ard et al., 2010), compared with those used in the present experiment. Comparisons of different diets with fixed forage-to-concentrate ratios using the same high-quality grass silage have not, to our knowledge, been the focus of many experiments. The main objective in the present trial was, therefore, to study the FA composition in milk fat with emphasis on the OBCFA, using 3 different proportions of grass silage in the diet. Furthermore, an additional objective was to study the correlation between diet components and OBCFA. In the present paper, the milk FA referred to as OBCFA are iso C14:0, iso $\mathrm{C} 15: 0$, anteiso $\mathrm{C} 15: 0, \mathrm{C} 15: 0$, iso $\mathrm{C} 16: 0$, iso $\mathrm{C} 17: 0$, $\mathrm{C} 17: 0$, and cis-9 C17:1.

\section{MATERIALS AND METHODS}

\section{Animals, Housing, and Experimental Design}

The cows were managed according to the Swedish Animal Welfare Act, Animal Welfare Ordinance (SFS, 1988), and the European Communities Council Directive $86 / 609 /$ EEC. The experiment was approved by the Uppsala Local Ethics Committee C173/6. The study was performed at Kungsängen Research Centre at the Swedish University of Agricultural Sciences in Uppsala during April 2008 and April 2009. In 2008, 7 primiparous and 17 multiparous dairy cows of the Swedish Red Breed were used. In 2009, 9 primiparous and 17 multiparous cows were used. The cows were completely randomly assigned to 1 of 3 diets that differed with regard to forage proportion (see below). All cows had reached lactation wk 25 at the start of the experiment, with a mean of 220 DIM $(\mathrm{SD}=15)$ in 2008 and 216 DIM $(\mathrm{SD}=35)$ in 2009. The mean BW was $611 \mathrm{~kg}(\mathrm{SD}=87)$ in 2008 and $648 \mathrm{~kg}(\mathrm{SD}=82)$ in 2009. The cows were housed indoors in a freestall barn with an automatic milking system (DeLaval International AB, Tumba, Sweden). At sampling, milking was performed starting at 0630 and $1630 \mathrm{~h}$. The cows were equipped with neck transponders and had access to 2 separate feeding areas, each with a feeding station for concentrate (DeLaval International $\mathrm{AB}$ ), and 10 forage mangers placed on weighing cells (BioControl AS, Rakkestad, Norway), for control and recording of individual feed intake.

\section{Experimental Diets, Feeds, and Feeding}

The cows were fed to cover their energy requirements according to Swedish recommendations for dairy cows (Spörndly, 2003). The 3 treatments differed in the proportions of grass silage in the diet on DM basis with low (LO), medium (MD), and high (HI) proportion of silage in the diet. The experiment was part of a longterm study in which the grass silage proportions were gradually increased from lactation mo 4 until drying off, with an increase in the silage proportion from 40 to $50 \%$ (LO), from $50 \%$ to $70 \%$ (MD), or from $50 \%$ to $90 \%$ (HI), over the lactation in the 3 treatments, respectively. The feed rations were adjusted once per week according to energy requirement, stage of lactation, and treatment group. Only minor changes were made in individual forage-to-concentrate ratios during the 3 wk preceding milk sampling. The average proportions of grass silage during these 3 wk were 48 (SD = 3.6), $68(\mathrm{SD}=3.0)$, and $84 \%(\mathrm{SD}=6.0)$ in diet $\mathrm{LO}$, $\mathrm{MD}$, and HI respectively.

The silage was made from leys dominated by timothy (Phleum pratense L.), meadow fescue (Festuca pratensis L.), and red clover (Trifolium pratense L.). The ingredients in the concentrate mixture were (\% of DM) oats (23.4), barley (23.2), peas (20.0), rapeseed cake (12.5), beet fiber (9.0), wheat bran (7.0), whole crushed rapeseed (2.5), and minerals and vitamins (2.4). The cows had free access to water cups, saltlicks, and minerals (\%): Ca (2.2), P (6.0), Mg (23.0), and Na (8.0; Gårdsmineral, Kvarnbyfoder, Sweden).

The forage mangers and feeding stations were accessible directly or via the milking unit throughout $24 \mathrm{~h}$, but the daily rations were distributed in 5 portions at 0000, 0600, 1100, 1600, and $2100 \mathrm{~h}$ to secure an even feed intake. One kilogram of concentrate was allotted in the milking unit at each milking and included in the total ration.

\section{Sample Collection and Analyses}

Feeds. Samples of silage were collected and frozen $5 \mathrm{~d}$ per week, and later pooled into 1 sample over a 14 -d period. The concentrate was sampled twice per week, and pooled in the same way as the silage. The pooled feed samples were then divided into 2: 1 for chemical analyses and 1 for FA analyses, and frozen at $-20^{\circ} \mathrm{C}$. Samples for FA analysis were later freeze dried using a Heto CD8 freeze dryer (Heto Lab Equipment, Allerød, Denmark). Crude fat content was determined according to standard procedures (EC, 2009). Conventional chemical analyses: DM, NDF, ADF, lignin, CP, water-soluble carbohydrates, and calculations of $\mathrm{ME}$ were performed as described by Bertilsson and Murphy (2003). 
Milk. At the time of the experiment, the milking unit was set to 2 milkings per day (morning and evening), to obtain samples at regular intervals. Morning and evening samples were pooled according to milk yield into 1 sample per cow. Samples for analyses of fat, CP, and lactose concentrations were preserved with bronopol (VWR International AB, Stockholm, Sweden), stored at $+4^{\circ} \mathrm{C}$, and the concentrations were determined by infrared spectroscopy using a MilkoScan FT120 analyzer (Foss Electric A/S, Hillerød, Denmark). Energycorrected milk was calculated according to Sjaunja et al. (1990). Samples for FA analyses were immediately frozen, without preservative, at $-80^{\circ} \mathrm{C}$ and subsequently thawed at the time of analysis, weighted to a daily mean composition, and pooled into 1 sample for each cow and day.

Lipid Analysis. Milk lipids were extracted by modification of the method described by Nourooz-Zadeh and Appelqvist (1988). Ten milliliters of hexane:isopropanol (3:2 vol/vol) was added to $2 \mathrm{~mL}$ of milk in a Teflon tube and shaken vigorously. Five milliliters of $\mathrm{Na}_{2} \mathrm{SO}_{4}$ (6.67\% solution) was added, shaken, and centrifuged at $1,900 \times g$ for $5 \mathrm{~min}$ at $18^{\circ} \mathrm{C}$ using a Sorvall RC-5 centrifuge (Thermo Scientific, Waltham, MA). The hexane layer was transferred into a second tube and evaporated with $\mathrm{N}_{2}$ until a final volume of $1 \mathrm{~mL}$ was reached. The lipid was weighed and then stored at $-80^{\circ} \mathrm{C}$ until methylation. Milk lipids were methylated using methanolic sodium methoxide, and the FA methyl esters (FAME) were analyzed using the method described by Shingfield et al. (2003). The FAME were analyzed using a gas chromatograph (Varian CP-3800; Agilent Technologies Inc., Santa Clara, CA) equipped with a flame ionization detector and split injector, fitted with a 100-m fused silica capillary column $\times 0.25-\mathrm{mm}$ i.d., coated with a $0.2-\mu \mathrm{m}$ film of cyanopropyl polysiloxane (CPSIL 88, Chrompack 7489; Chrompack, Middelburg, the Netherlands). Hydrogen was used as the carrier gas. Injector and detector temperatures were maintained at $255^{\circ} \mathrm{C}$. The total FAME profile in a $2-\mu \mathrm{L}$ sample, at a split ratio of 1:50, was determined using a temperature gradient program. Following sample injection, the column temperature was maintained at $70^{\circ} \mathrm{C}$ for $4 \mathrm{~min}$, increased at a rate of $8^{\circ} \mathrm{C} / \mathrm{min}$ to $110^{\circ} \mathrm{C}$, raised to $170^{\circ} \mathrm{C}$ at a rate of $5^{\circ} \mathrm{C} / \mathrm{min}$, held at $170^{\circ} \mathrm{C}$ for $10 \mathrm{~min}$, and increased at $4^{\circ} \mathrm{C} / \mathrm{min}$ to a final temperature of $240^{\circ} \mathrm{C}$, which was maintained for 25 min. Peaks were routinely identified by comparison of retention times with FAME standards (GLC 463; Nu-Chek Prep Inc., Elysian, MN) and mass spectrometry. Peak areas were integrated using a Star Chromatography Workstation with software version 5.5 (Varian Inc., Palo Alto CA).

Feed lipids were extracted by the method described by Folch et al. (1957). The FAME were prepared from feed lipids using the procedure by Appelqvist (1968) and analyzed using a gas chromatograph, Varian CP3800 (Agilent Technologies Inc.), fitted with a flame ionization detector and a capillary column BPX70 (SGE Inc., Austin TX; length 50-m × 0.22-mm i.d., $0.25-\mu \mathrm{m}$ film thickness). Helium was used as the carrier gas. The column temperature was programmed to increase by $2^{\circ} \mathrm{C} / \mathrm{min}$ from $158^{\circ} \mathrm{C}(5 \mathrm{~min})$ to $220^{\circ} \mathrm{C}(8$ $\min )$. Injector and detector temperatures were 230 and $250^{\circ} \mathrm{C}$, respectively. The FA were identified by comparing the obtained peaks with those of reference standards (Nu-Chek Prep Inc.). Peak areas were integrated using workstation Galaxie Chromatography software (version 1.9; Agilent Technologies Inc.).

\section{Statistical Analysis and Calculations}

Data were analyzed using SAS software (version 9.1; SAS Institute Inc., Cary, NC). Intake and milk production were analyzed using PROC MIXED, using the fixed effects of year and diet. Cow within diet was the random variable. Effects of parity and interactions between diet and parity were found to be nonsignificant and excluded from the final model. As 10 cows (out of 50) were present in both years (randomized to new diets), carryover effects from the previous diet were tested, but found to be nonsignificant and, therefore, excluded from the model.

Least squares means were calculated using the LSMEANS/PDIFF option and statistical differences between feed intake variables were determined following the Tukey adjustment $(P<0.05)$, whereas differences between milk production variables were determined using orthogonal polynomial contrasts $(P<0.05)$. The threshold for tendency was set at $P<0.10$.

The data set included the results from analysis of individual daily milk samples and averages of the cows' individual feed intakes during the same week the milk was sampled. Multiple regression analysis on diet composition and OBCFA was performed using PROC STEPWISE.

Data from the 2 separate years were collected to obtain a sufficient number of observations, and to ensure that results were not based on specific conditions that can occur during a certain time period. As the effect of year was not the main interest of this study, year will not be discussed further. Daily intake of feed FA was calculated from the internal standard (iso 17:1) used in the gas chromatography analyses.

\section{RESULTS}

\section{Feed Intake}

The chemical compositions and FA content of the feeds are presented in Table 1. The FA compositions of 
Table 1. Chemical composition and FA content of the feeds (data from 2 yr)

\begin{tabular}{|c|c|c|}
\hline \multirow[b]{2}{*}{ Item } & \multicolumn{2}{|c|}{ Feed } \\
\hline & $\begin{array}{l}\text { Silage } \\
(\mathrm{n}=2)\end{array}$ & $\begin{array}{c}\text { Concentrate } \\
\quad(\mathrm{n}=2)\end{array}$ \\
\hline DM, \% & 39.2 & 88.2 \\
\hline $\mathrm{ME}, \mathrm{MJ} / \mathrm{kg}$ of $\mathrm{DM}$ & 11.2 & $13.2^{1}$ \\
\hline \multicolumn{3}{|c|}{ Chemical composition, \% of DM } \\
\hline $\mathrm{CP}$ & 15.4 & 17.0 \\
\hline NDF & 44.4 & 21.6 \\
\hline Starch $^{2}$ & NA & 32.5 \\
\hline Crude fat & 2.7 & 3.8 \\
\hline Ash & 8.3 & 5.8 \\
\hline \multicolumn{3}{|l|}{$\mathrm{FA}, \mathrm{g} / \mathrm{kg}$ of $\mathrm{DM}$} \\
\hline C16:0 & 2.22 & 4.8 \\
\hline C18:0 & 0.21 & 0.74 \\
\hline cis-9 C18:1 & 0.48 & 13.88 \\
\hline cis-9,cis-12 C18:2n-6 & 2.37 & 6.36 \\
\hline cis-9,cis-12,cis-15 C18:3n-3 & 6.80 & 0.86 \\
\hline Other $\mathrm{FA}^{3}$ & 0.60 & 1.82 \\
\hline Total FA & 12.7 & 28.5 \\
\hline
\end{tabular}

${ }^{1}$ Metabolizable energy reported from feed manufacturer.

${ }^{2}$ Starch was assumed to be negligible in grass silage and not analyzed (NA).

${ }^{3}$ Other $\mathrm{FA}=$ cis-9 $\mathrm{C} 16: 1, \mathrm{C} 17: 0$, cis-11 C18:1, C20:0, cis-11 C20:1, C20:3n-6, and C22:0.

the 2 feeds showed that the grass silage was dominated by $\mathrm{C} 18: 3 \mathrm{n}-3$, followed by $\mathrm{C} 18: 2 \mathrm{n}-6$. In concentrates, the dominating FA was cis-9 C18:1, followed by C18:2n-6. The intake of DM, ME, CP, and crude fat was not influenced by treatment group. Increased proportion of forage decreased the intake of starch and increased the intake of NDF, as planned. The intake of total FA decreased with increased forage proportion, and significant differences were observed between the 3 diets in intake of all individual FA, except for the intake of C16:0. The intake of C16:0 did not differ between diet $\mathrm{MD}$ and HI, but was lower in these groups compared with diet LO (Table 2).

\section{Milk Yield and Composition}

Increasing the proportion of grass silage linearly increased the concentrations of $\mathrm{C} 15: 0$, iso $\mathrm{C} 15: 0$, cis- 9 C16:1, C17:0, cis-9,trans-11 C18:2 conjugated linoleic acid (CLA), C18:3n-3, and total OBCFA. A quadratic and linear increase in the concentration of $\mathrm{C} 16: 0$ was also shown. The concentrations of C10:0, C18:0, C18:2n-6, and $\mathrm{C} 20: 3 \mathrm{n}-6$ decreased linearly with increasing forage proportion, and the $\mathrm{C} 18: 2 \mathrm{n}-6: \mathrm{C} 18: 3 \mathrm{n}-3$ ratio decreased quadratic and linearly (Table 3 ). Increasing the forage proportion decreased milk, ECM, and protein yields ( $\mathrm{kg} / \mathrm{cow}$ per day), quadratically and linearly. Milk fat yield decreased linearly with increasing proportion of silage, whereas no significant effects were observed on fat, protein, or lactose concentration (Table 4). The results from the multiple regression analysis (partial- $\mathrm{R}^{2}$, $P<0.05$ ), showed that the concentration of total OBCFA had the strongest positive correlation with dietary content of NDF, followed by $\mathrm{C} 15: 0$ and iso $\mathrm{C} 15: 0\left(\mathrm{R}^{2}=\right.$ $0.36,0.28$, and 0.24 , respectively). Starch had a strong negative correlation with $\mathrm{C} 17: 0\left(\mathrm{R}^{2}=0.45\right)$.

Table 2. Daily DMI of feed, ME, and FA in diets of dairy cows fed a low (LO), medium (MD), or high (HI) proportion of grass silage (data from $2 \mathrm{yr}$ )

\begin{tabular}{|c|c|c|c|c|c|}
\hline \multirow[b]{2}{*}{ Item } & \multicolumn{3}{|c|}{$\operatorname{Diet}^{1}$} & \multirow[b]{2}{*}{ SEM } & \multirow[b]{2}{*}{$P$-value } \\
\hline & $\begin{array}{c}\mathrm{LO} \\
(\mathrm{n}=17)\end{array}$ & $\begin{array}{c}\text { MD } \\
(\mathrm{n}=20)\end{array}$ & $\begin{array}{c}\text { HI } \\
(\mathrm{n}=13)\end{array}$ & & \\
\hline Forage, $\%$ of total DMI & $49^{c}$ & $69^{\mathrm{b}}$ & $86^{\mathrm{a}}$ & 0.96 & 0.001 \\
\hline DMI, $\mathrm{kg} / \mathrm{d}$ & 19.7 & 19.5 & 20.3 & 0.61 & 0.58 \\
\hline Concentrate, $\mathrm{kg}$ of $\mathrm{DM} / \mathrm{d}$ & $10.2^{\mathrm{a}}$ & $6.1^{\mathrm{b}}$ & $2.9^{\mathrm{c}}$ & 0.31 & 0.001 \\
\hline $\mathrm{CP}, \mathrm{kg} / \mathrm{d}$ & 3.19 & 3.04 & 3.06 & 0.92 & 0.40 \\
\hline Crude fat, $\mathrm{kg} / \mathrm{d}$ & 0.63 & 0.58 & 0.57 & 0.02 & 0.07 \\
\hline $\mathrm{NDF}, \mathrm{kg} / \mathrm{d}$ & $6.38^{\mathrm{c}}$ & $7.13^{\mathrm{b}}$ & $8.13^{\mathrm{a}}$ & 0.21 & 0.002 \\
\hline Starch, $\mathrm{kg} / \mathrm{d}$ & $3.31^{\mathrm{a}}$ & $1.97^{\mathrm{b}}$ & $0.93^{\mathrm{c}}$ & 0.10 & 0.001 \\
\hline $\mathrm{ME}, \mathrm{MJ} / \mathrm{d}$ & 239 & 225 & 224 & 6.9 & 0.21 \\
\hline \multicolumn{6}{|l|}{$\mathrm{FA}, \mathrm{g} / \mathrm{d}$} \\
\hline C16:0 & $62.9^{\mathrm{a}}$ & $53.4^{\mathrm{b}}$ & $47.6^{\mathrm{b}}$ & 1.73 & 0.001 \\
\hline C18:0 & $8.9^{\mathrm{a}}$ & $7.1^{\mathrm{b}}$ & $5.9^{\mathrm{c}}$ & 0.27 & 0.001 \\
\hline cis-9 C18:1 & $138.1^{\mathrm{a}}$ & $86.7^{\mathrm{b}}$ & $47.0^{\mathrm{c}}$ & 4.17 & 0.001 \\
\hline cis-9,cis-12 C18:2n-6 & $103.0^{\mathrm{a}}$ & $79.6^{\mathrm{b}}$ & $63.0^{\mathrm{c}}$ & 2.93 & 0.001 \\
\hline cis-9,cis-12,cis-15 C18:3n-3 & $70.6^{\mathrm{c}}$ & $87.6^{\mathrm{b}}$ & $103.6^{\mathrm{a}}$ & 2.78 & 0.001 \\
\hline Other $\mathrm{FA}^{2}$ & $23.0^{\mathrm{a}}$ & $18.1^{\mathrm{b}}$ & $15.0^{\mathrm{c}}$ & 0.71 & 0.001 \\
\hline Total FA & $407.0^{\mathrm{a}}$ & $332.7^{\mathrm{b}}$ & $282.2^{\mathrm{c}}$ & 10.97 & 0.001 \\
\hline
\end{tabular}


Table 3. Effect of diet on milk FA (g/100 g of FA) from dairy cows fed a low (LO), medium (MD), or high (HI) proportion of grass silage (data from 2 yr)

\begin{tabular}{|c|c|c|c|c|c|c|}
\hline \multirow[b]{2}{*}{ FA } & \multicolumn{3}{|c|}{$\operatorname{Diet}^{1}$} & \multirow[b]{2}{*}{ SEM } & \multicolumn{2}{|c|}{ Significance $^{2}$} \\
\hline & $\begin{array}{c}\mathrm{LO} \\
(\mathrm{n}=17)\end{array}$ & $\begin{array}{c}\text { MD } \\
(\mathrm{n}=20)\end{array}$ & $\begin{array}{c}\text { HI } \\
(\mathrm{n}=13)\end{array}$ & & Linear & Quadratic \\
\hline $\mathrm{C} 4: 0$ & 2.61 & 2.24 & 2.68 & 0.38 & NS & NS \\
\hline C6:0 & 2.15 & 1.98 & 2.11 & 0.13 & NS & $\mathrm{NS}$ \\
\hline $\mathrm{C} 8: 0$ & 1.49 & 1.41 & 1.38 & 0.05 & $\mathrm{NS}$ & $\mathrm{NS}$ \\
\hline C10:0 & 3.68 & 3.33 & 3.26 & 0.13 & $*$ & NS \\
\hline $\mathrm{C} 12: 0$ & 3.93 & 3.75 & 3.63 & 0.15 & NS & NS \\
\hline cis-9 C12:1 & 0.18 & 0.17 & 0.17 & 0.01 & $\mathrm{NS}$ & $\mathrm{NS}$ \\
\hline $\mathrm{C} 14: 0$ & 12.6 & 12.4 & 12.2 & 0.29 & NS & NS \\
\hline iso $\mathrm{C} 14: 0$ & 0.07 & 0.07 & 0.08 & 0.01 & $\mathrm{NS}$ & $\mathrm{NS}$ \\
\hline cis-9 C14:1 & 1.00 & 1.04 & 0.97 & 0.07 & $\mathrm{NS}$ & $\mathrm{NS}$ \\
\hline $\mathrm{C} 15: 0$ & 0.94 & 1.00 & 1.06 & 0.03 & $*$ & $\mathrm{NS}$ \\
\hline iso $\mathrm{C} 15: 0$ & 0.18 & 0.19 & 0.21 & 0.01 & $*$ & $\mathrm{NS}$ \\
\hline anteiso $\mathrm{C} 15: 0$ & 0.39 & 0.40 & 0.42 & 0.02 & NS & NS \\
\hline $\mathrm{C} 16: 0$ & 25.9 & 29.1 & 29.8 & 0.83 & $* * *$ & $*$ \\
\hline iso C16:0 & 0.26 & 0.29 & 0.26 & 0.03 & NS & $\mathrm{NS}$ \\
\hline cis-9 C16:1 $1^{3}$ & 1.04 & 1.31 & 1.72 & 0.08 & $* * *$ & $\mathrm{NS}$ \\
\hline C17:0 & 0.53 & 0.57 & 0.67 & 0.02 & $* * *$ & $\mathrm{NS}$ \\
\hline iso $\mathrm{C} 17: 0$ & 0.33 & 0.29 & 0.47 & 0.07 & NS & $\mathrm{NS}$ \\
\hline cis-9 C17:1 & 0.00 & 0.01 & 0.02 & 0.008 & NS & NS \\
\hline C18:0 & 12.0 & 11.1 & 9.8 & 0.40 & $* * *$ & NS \\
\hline$\Sigma$ cis $\mathrm{C} 18: 1$ & 22.4 & 21.3 & 21.0 & 0.61 & NS & NS \\
\hline$\Sigma$ trans $\mathrm{C} 18: 1$ & 2.73 & 2.44 & 2.43 & 0.24 & NS & $\mathrm{NS}$ \\
\hline cis-9,trans-11 C18:2 $\mathrm{CLA}^{4}$ & 0.67 & 0.80 & 0.90 & 0.08 & $*$ & NS \\
\hline cis-9,cis-12 C18:2n-6 & 1.81 & 1.46 & 1.24 & 0.08 & $* * *$ & NS \\
\hline cis-9,cis-12,cis-15 C18:3n-3 & 0.65 & 0.76 & 0.90 & 0.06 & $* *$ & NS \\
\hline $\mathrm{C} 20: 0$ & 0.21 & 0.22 & 0.21 & 0.01 & NS & NS \\
\hline cis-11,cis-14 C20:2n-6 & 0.00 & 0.02 & 0.01 & 0.01 & NS & NS \\
\hline cis-11,cis-14,cis-17 C20:3n-3 & 0.01 & 0.05 & 0.03 & 0.03 & NS & NS \\
\hline cis-8,cis-11,cis-14 C20:3n-6 & 0.07 & 0.05 & 0.03 & 0.01 & $*$ & NS \\
\hline cis- 5, cis- 8, cis- 11, cis- 14 C20:4n-6 & 0.04 & 0.04 & 0.05 & 0.02 & $\mathrm{NS}$ & NS \\
\hline cis-5,cis-8,cis-11,cis-14,cis-17 C20:5n-3 & 0.06 & 0.16 & 0.15 & 0.07 & NS & NS \\
\hline $\mathrm{C} 22: 0$ & 0.08 & 0.08 & 0.08 & 0.006 & NS & NS \\
\hline cis- 13, cis- 16 C22:2n-6 & 0.02 & 0.02 & 0.04 & 0.01 & $\mathrm{NS}$ & NS \\
\hline cis-7,cis-10,cis-13,cis-16,cis-19 C22:5n-3 & 0.02 & 0.02 & 0.04 & 0.01 & NS & NS \\
\hline cis-4,cis-7,cis-10,cis-13,cis-16 C22:5n-6 & 0.01 & 0.02 & 0.01 & 0.01 & NS & NS \\
\hline $\mathrm{C} 24: 0$ & 0.09 & 0.09 & 0.08 & 0.01 & $\mathrm{NS}$ & NS \\
\hline cis-15 C24:1 & 0.01 & 0.02 & 0.01 & 0.01 & NS & NS \\
\hline Unknown & 1.73 & 1.66 & 1.77 & 0.37 & NS & NS \\
\hline Total SFA & 67.3 & 68.5 & 68.4 & 0.97 & NS & NS \\
\hline Total MUFA & 27.5 & 26.3 & 26.5 & 0.77 & NS & NS \\
\hline Total PUFA & 3.49 & 3.58 & 3.42 & 0.30 & $\mathrm{NS}$ & NS \\
\hline MCSFA $^{5}$ & 20.2 & 19.5 & 19.1 & 0.50 & NS & NS \\
\hline Total OBCFA ${ }^{6}$ & 2.77 & 2.85 & 3.25 & 0.10 & $* *$ & NS \\
\hline C18:2n-6/C18:3n-3 & 2.9 & 2.0 & 1.6 & 0.19 & $* * *$ & $*$ \\
\hline
\end{tabular}

${ }^{1} \mathrm{LO}=50 \%, \mathrm{MD}=70 \%$, and $\mathrm{HI}=85 \%$ grass silage in the diet (DM basis).

${ }^{2}$ Significance of linear and quadratic responses to increased proportion of grass silage.

${ }^{3}$ Co-eluted with anteiso C17:0.

${ }^{4}$ Conjugated linoleic acid (CLA) co-eluted with cis-9,trans-7 C18:2 CLA and cis-10,trans-8 C18:2 CLA.

${ }^{5}$ Medium-chain SFA (MCSFA) = C10:0, C12:0, and C14:0.

${ }^{6}$ Total odd- and branched-chain FA (OBCFA) = iso C14:0, iso C15:0, anteiso C15:0, C15:0, iso C16:0, iso C17:0, C17:0, and cis-9 C17:1.

$* P<0.05 ; * * P<0.01 ; * * * P<0.001$.

\section{DISCUSSION}

The main objective of this study was to evaluate the effect of predetermined proportions of grass silage in the diet on the OBCFA composition in milk. The proportions of grass silage in the present study were chosen to cover a range of alternatives that can be found in Northern Europe, from intensive to extensive production systems, including diets common in conventional as well as organic production systems. The level of forage in the diets of dairy cows depends not only on whether the production system is organic or conventional, but also differs between countries and regions. Therefore, a fairly wide range in forage proportions were covered in the treatments studied, from 50 to $85 \%$ of DMI. 
Table 4. Effect of diet on milk yield and milk composition from dairy cows fed a low (LO), medium (MD), or high (HI) proportion of grass silage (data from 2 yr)

\begin{tabular}{|c|c|c|c|c|c|c|}
\hline \multirow[b]{2}{*}{ Item } & \multicolumn{3}{|c|}{$\operatorname{Diet}^{1}$} & \multirow[b]{2}{*}{ SEM } & \multicolumn{2}{|c|}{ Significance $^{2}$} \\
\hline & $\begin{array}{c}\mathrm{LO} \\
(\mathrm{n}=17)\end{array}$ & $\begin{array}{c}\mathrm{MD} \\
(\mathrm{n}=20)\end{array}$ & $\begin{array}{c}\mathrm{HI} \\
(\mathrm{n}=13)\end{array}$ & & Linear & Quadratic \\
\hline Milk yield, kg/d & 31.1 & 25.8 & 24.8 & 1.19 & $* * *$ & * \\
\hline $\mathrm{ECM}, \mathrm{kg} / \mathrm{d}$ & 32.2 & 28.0 & 26.6 & 1.07 & $* * *$ & * \\
\hline Milk fat, $\%$ & 4.12 & 4.46 & 4.45 & 0.15 & NS & NS \\
\hline Milk protein, \% & 3.64 & 3.69 & 3.56 & 0.07 & NS & NS \\
\hline Milk lactose, \% & 4.81 & 4.79 & 4.79 & 0.03 & NS & NS \\
\hline Milk fat yield, $\mathrm{kg} / \mathrm{d}$ & 1.27 & 1.14 & 1.10 & 0.05 & $* *$ & NS \\
\hline Milk protein yield, $\mathrm{kg} / \mathrm{d}$ & 1.13 & 0.95 & 0.88 & 0.04 & $* * *$ & $*$ \\
\hline
\end{tabular}

\section{Milk OBCFA}

In ruminants, linear odd-chain FA C15:0 and C17:0 can be synthesized de novo from propionate in the mammary gland, and in adipose tissue (Vlaeminck et al., 2006a), and some researchers (Cabrita et al., 2007; Dewhurst et al., 2007) suggested substantial de novo synthesis in animal tissues. It has also been suggested that cis-9 $\mathrm{C} 17: 1$ is solely produced from C17:0 by $\Delta^{9}$-desaturase in the mammary gland (Vlaeminck et al., 2006a). In the present study, the concentrations of C15:0, iso C15:0, C17:0 and total OBCFA in milk increased with increased forage proportion. Shingfield et al. (2005), comparing 2 levels of concentrate with oil supplement on a diet based on grass silage, found a significantly higher concentration of $\mathrm{C} 17: 0$ and a tendency for a higher concentration of iso C14:0 with a high proportion of forage in the diet. Cabrita et al. (2007) suggested from a study on corn silage-based diets that more efficient rumen fermentation was obtained with low-starch diets (15\% starch of DMI), resulting in increased concentrations of odd branchedchain FA in milk. In contrast, no relationship between starch content in the diet and the concentration of odd branched-chain FA was found in the present study. However, the increased levels of total OBCFA and iso C15:0 with increased proportion of grass silage in the present study correspond to the conclusions from the review by Vlaeminck et al. (2006a). In addition, Vlaeminck et al. (2006c) showed that the milk iso FA were positively related to rumen proportions of acetate and, thus, may be used in prediction equations of rumen fermentation patterns. The same author also found a positive relationship of the linear odd-chain FA with rumen proportions of propionate, whereas the reports on the anteiso FA are somewhat inconsistent. Vlaeminck et al. (2006a) described an increase in anteiso and linear oddchain milk FA with a decreased proportion of forage.
Cabrita et al. (2007) reported decreased concentrations of anteiso FA in milk with increased inclusion of starch in the diet, as did Vlaeminck et al. (2006b), who also found a strong relationship between increased forage proportion and the proportion of anteiso C15:0 of total rumen OBCFA.

The major differences between the diets in the present experiment were in the proportions of NDF and starch, and it was also shown from the multiple regression analysis that NDF was the component that affected the total OBCFA composition the most. Vlaeminck et al. (2006a) reported influence of NDF on the concentrations of milk iso C14:0 and iso C15:0. These relationships may reflect the proportion of cellulolytic bacteria in the rumen with different forage-to-concentrate ratios. Bas et al. (2003) reported strong positive correlations of NDF with total iso, total anteiso, and total odd-chain FA in duodenal digesta of goats. Cabrita et al. (2003) suggested that the proportions of linear and branched C17 milk FA are reflections of the protein supply. In addition, Vlaeminck et al. (2005) evaluated equations to predict duodenal flow of microbial mass, and found strong positive correlations with C17 milk FA. In contrast to the results obtained in the afore-mentioned studies, Dewhurst et al. (2007) found strong positive correlations of microbial mass in the duodenum with concentrate level, but no such change in OBCFA was found in milk.

The milk FA composition is affected by stage of lactation, particularly by the mobilization of adipose tissue at the onset of lactation. The release of longchain FA from adipose tissue decreases the proportion of shorter FA, partly because of an inhibitory effect on the de novo synthesis. The short-chain FA then increase as lactation proceeds until wk 8 to 10 (Palmquist et al., 1993). Reports on the effect of lactation stage on OBCFA are scarce, but Craninx et al. (2008) reported increased concentrations during early lactation, with 
constant levels after 10 to 16 wk of lactation in iso C14:0, iso C15:0, C15:0, and anteiso C15:0. Levels of C17:0 and cis-9 C17:1 decreased, whereas iso C17:0 remained constant throughout the lactation. In the present study, the cows were in late lactation $(>200$ DIM) and, therefore, the effect of lactation week was considered to be negligible. However, changes in FA composition due to lactation stage need to be taken into account if the OBCFA profile should be used as a management tool in the future.

\section{Milk FA of Interest for Human Health}

In the present study, milk C18:2n-6 decreased as the proportion of forage increased, and is in agreement with previous reports (Shingfield et al., 2005; Dewhurst et al., 2007). This was probably an effect of the decreasing amount of concentrate in the diet and associated with a lower intake of C18:2n-6. Total intake of C18:3n-3 increased with increased forage proportion and this was reflected in increased concentration of C18:3n-3 in milk. Similar effects of low levels of concentrate in grass silage-based diets were reported by Shingfield et al. (2005). The 18:2n-6:18:3n-3 ratio in milk was deceased with increased forage proportion; thus, milk from cows on the high-forage diets had a healthier composition in that respect (Simopoulos, 2002). When the proportion of grass silage increased, the concentration of CLA in milk increased. Increased levels of CLA are typically shown when the cows are on pasture or fed diets with high concentration of C18:2n- 6 or trans-11 C18:1 (Griinari et al., 2000; Chilliard et al., 2007). The concentration of C18:0, which is the end product in rumen biohydrogenation (Harfoot and Hazlewood, 1997), decreased with increased proportion of forage. This was probably due to the lower intake of unsaturated $\mathrm{FA}$ when the amount of concentrate was lower (Table 2). However, the extent of biohydrogenation is affected by several factors. Forage-based diets may stimulate cellulolytic bacteria and thus enhance the rate of biohydrogenation (Harfoot and Hazlewood, 1997). The large variation in NDF content in forages influences the rumen passage rate, and Dewhurst et al. (2003a) suggested that high passage rate was one cause of reduced biohydrogenation in legume silages. The extent of $\Delta^{9}$-desaturase activity in mammary tissue influences the proportions of saturated versus monounsaturated FA in milk fat (Griinari et al., 2000).

The plasma cholesterol-raising FA C12:0 and C14:0 were not significantly affected by diet, whereas C16:0 increased with increased forage proportion. The reasons for this may partly be explained by an increased de novo synthesis from acetate and BHBA with increased fiber inclusion in the diet, and a lower intake of C18 FA and, thus, less inhibitory effect on the de novo synthesis in diets MD and HI. Dewhurst et al. (2003b), who studied 2 levels of concentrate in combination with grass or clover silage, reported similar effects of concentrate level on C16:0.

\section{CONCLUSIONS}

Increasing the proportions of high-quality grass silage to dairy cows from 50 to $85 \%$ of DMI increased the concentrations of the linear odd-chain FA, iso C15:0, and total OBCFA in milk. The reflection of forage proportion in milk OBCFA suggests that total OBCFA concentrations in milk may be useful in the future as an indicator that forage intake has decreased below a certain level, under conditions when it is not possible to measure individual forage intake. Increasing the proportions of grass silage in the diet affected the concentrations of C18:3n-3, C18:2n-6, and CLA in milk in a beneficial way, although the contribution of essential FA from milk is low in the human diet.

\section{ACKNOWLEDGMENTS}

The authors thank Mikko Griinari (Clanet Ltd., Helsinki, Finland) for helpful advice on the manuscript. The experiment was funded by the Swedish Research Council for Environment, Agricultural Sciences and Spatial Planning (FORMAS, Stockholm, Sweden) and the Swedish Board of Agriculture (Jönköping, Sweden). The authors thank Gunilla Helmersson and the staff in the barn at Kungsängen Research Centre (Uppsala, Sweden) for taking care of the animals and the staff at the Kungsängen laboratory and at the Department of Food Science for performing analyses.

\section{REFERENCES}

AlZahal, O., M. M. Or-Rashid, M. A. Steele, and B. W. McBride. 2011. The effect of subacute ruminal acidosis on milk fatty acid profile in dairy cattle. Can. J. Anim. Sci. 91:502.

Appelqvist, L.-Å. 1968. Rapid methods of lipid extraction and fatty acid methyl ester preparation for seed and leaf tissue with special remarks on preventing accumulation of lipid contaminants. Arkiv för Kemi 28:551-570. (Kungliga Svenska Vetenskapsakademien).

Bas, P., H. Archimède, A. Rouzeau, and D. Sauvant. 2003. Fatty acid composition of mixed-rumen bacteria: Effect of concentration and type of forage. J. Dairy Sci. 86:2940-2948.

Bertilsson, J., and M. Murphy. 2003. Effects of feeding clover silages on feed intake, milk production and digestion in dairy cows. Grass Forage Sci. 58:309-322.

Cabrita, A. R. J., R. J. B. Bessa, S. P. Alves, R. J. Dewhurst, and A. J. M. Fonseca. 2007. Effects of dietary protein and starch on intake, milk production, and milk fatty acid profiles of dairy cows fed corn silage-based diets. J. Dairy Sci. 90:1429-1439.

Cabrita, A. R. J., A. J. M. Fonseca, R. J. Dewhurst, and E. Gomes. 2003. Nitrogen supplementation of corn silages. 2. Assessing rumen function using fatty acid profiles of bovine milk. J. Dairy Sci. 86:4020-4032. 
Chilliard, Y., F. Glasser, A. Ferlay, L. Bernard, J. Rouel, and M. Doreau. 2007. Diet, rumen biohydrogenation and nutritional quality of cow and goat milk fat. Eur. J. Lipid Sci. Technol. 109:828855.

Colman, E., W. B. Fokkink, M. Craninx, J. R. Newbold, B. De Baets, and V. Fievez. 2010. Effect of induction of subacute ruminal acidosis on milk fat profile and rumen parameters. J. Dairy Sci. 93:4759-4773.

Craninx, M., A. Steen, H. Van Laar, T. Van Nespen, J. Martín-Tereso, B. De Baets, and V. Fievez. 2008. Effect of lactation stage on the odd- and branched-chain milk fatty acids of dairy cattle under grazing and indoor conditions. J. Dairy Sci. 91:2662-2677.

Dewhurst, R. J., R. T. Evans, N. D. Scollan, J. M. Moorby, R. J. Merry, and R. J. Wilkins. 2003a. Comparison of grass and legume silages for milk production. 2 . In vivo and in sacco evaluations of rumen function. J. Dairy Sci. 86:2612-2621.

Dewhurst, R. J., W. J. Fisher, J. K. S. Tweed, and R. J. Wilkins. 2003b. Comparison of grass and legume silages for milk production. 1. Production responses with different levels of concentrate. J. Dairy Sci. 86:2598-2611.

Dewhurst, R. J., J. M. Moorby, B. Vlaeminck, and V. Fievez. 2007. Apparent recovery of duodenal odd- and branched-chain fatty acids in milk of dairy cows. J. Dairy Sci. 90:1775-1780.

EC (European Commission). 2008. European Commission Regulation (EC) No 889/2008 of 5 September 2008 laying down detailed rules for the implementation of Council Regulation (EC) No 834/2007 on organic production and labelling of organic products with regard to organic production, labelling and control. Official Journal of the European Union 18.9.2008. European Commission, Brussels, Belgium.

EC (European Commission). 2009. European Commission Regulation (EC) No 152/2009 of 27 January 2009 laying down the methods of sampling and analysis for the official control of feed. Official Journal of the European Union L/54. 26.2.2009. European Commission, Brussels, Belgium.

Emanuelson, M., C. Cederberg, J. Bertilsson, and H. Rietz. 2006. Närodlat foder till mjölkkor - en kunskapsuppdatering. [Near farm cultivated feeds for dairy cows - A knowledge update.] Rapport no. 7059-P. Swedish Dairy Association, Stockholm, Sweden.

Folch, J., M. Lees, and G. H. Sloane Stanley. 1957. A simple method for the isolation and purification of total lipids from animal tissues. J. Biol. Chem. 226:497-509.

Griinari, J. M., B. A. Corl, S. H. Lacy, P. Y. Chouinard, K. V. V. Nurmela, and D. E. Bauman. 2000. Conjugated linoleic acid is synthesized endogenously in lactating dairy cows by $\Delta^{9}$-desaturase. J. Nutr. 130:2285-2291.

Harfoot, C. G., and G. P. Hazlewood. 1997. Lipid metabolism in the rumen. Pages 382-426 in The Rumen Microbial Ecosystem. 2nd ed. P. N. Hobson and C. S. Stewart, ed. Blackie Academic and Professional, London, UK.
Khiaosa-Ard, R., F. Klevenhusen, C. R. Soliva, M. Kreuzer, and F. Leiber. 2010. Transfer of linoleic and linolenic acid from feed to milk in cows fed isoenergetic diets differing in proportion and origin of concentrates and roughages. J. Dairy Res. 77:331-336.

Nourooz-Zadeh, J., and L.-A. Appelqvist. 1988. Cholesterol oxides in Swedish foods and food ingredients: Milk powder products. J. Food Sci. 53:74-79.

Palmquist, D. L., A. D. Beaulieu, and D. M. Barbano. 1993. Feed and animal factors influencing milk fat composition. J. Dairy Sci. $76: 1753-1771$

SFS. 1988. Swedish Animal Welfare Ordinance 1988:539, section 10. Ministry of Agriculture, Food and Fisheries, Stockholm, Sweden.

Shingfield, K. J., S. Ahvenjärvi, V. Toivonen, A. Ärölä, K. V. V. Nurmela, P. Huhtanen, and J. M. Griinari. 2003. Effect of dietary fish oil on biohydrogenation of fatty acids and milk fatty acid content in cows. Anim. Sci. 77:165-179.

Shingfield, K. J., C. K. Reynolds, B. Lupoli, V. Toivonen, M. P. Yurawecz, P. Delmonte, J. M. Griinari, A. S. Grandison, and D. E. Beever. 2005. Effect of forage type and proportion of concentrate in the diet on milk fatty acid composition in cows given sunflower oil and fish oil. Anim. Sci. 80:225-238.

Simopoulos, A. P. 2002. The importance of the ratio of omega-6/omega-3 essential fatty acids. Biomed. Pharmacother. 56:365-379.

Sjaunja, L. O., L. Baevre, L. Junkkarinen, J. Pedersen, and J. Setälä 1990. A Nordic proposal for an energy corrected milk (ECM) formula. Pages 156-192 in Performance Recording of Animals: 27th Biennial Session of the International Committee for Animal Recording, Paris, France.

Spörndly, R. 2003. Fodertabeller för idisslare. Feedtables for ruminants. Rapport 257. Department of Animal Nutrition and Management, Swedish University of Agricultural Sciences, Uppsala, Sweden.

Vlaeminck, B., C. Dufour, A. M. van Vuuren, A. R. J. Cabrita, R. J. Dewhurst, D. Demeyer, and V. Fievez. 2005. Use of odd and branched-chain fatty acids in rumen contents and milk as a potential microbial marker. J. Dairy Sci. 88:1031-1042.

Vlaeminck, B., V. Fievez, A. R. J. Cabrita, A. J. M. Fonseca, and R. J. Dewhurst. 2006a. Factors affecting odd- and branched-chain fatty acids in milk: A review. Anim. Feed Sci. Technol. 131:389-417.

Vlaeminck, B., V. Fievez, D. Demeyer, and R. J. Dewhurst. 2006b. Effect of forage:concentrate ratio on fatty acid composition of rumen bacteria isolated from ruminal and duodenal digesta. J. Dairy Sci. 89:2668-2678.

Vlaeminck, B., V. Fievez, S. Tamminga, R. J. Dewhurst, A. van Vuuren, D. De Brabander, and D. Demeyer. 2006c. Milk odd- and branched-chain fatty acids in relation to the rumen fermentation pattern. J. Dairy Sci. 89:3954-3964. 